\title{
ANALISIS HUBUNGANADVERSITY QUETIENT TERHADAP PRESTASI AKADEMIK MAHASISWA UNIVERSITAS RIAU KEPULAUAN
}

\section{ANALYSIS OF CORRELATION BETWEEN ADVERSITY QUOTIENT AND STUDENTS' ACADEMIC ACHIEVEMENTS OF RIAU KEPULAUAN UNIVERSITY}

\author{
Riska Novia Sari ${ }^{1}$, Putri Yulia ${ }^{2}$ \\ ${ }^{1,2}$ Program StudiPendidikan Matematika, Fakultas Keguruan dan Ilmu Pendidikan, \\ Universitas Riau Kepulauan,Batam, Indonesia \\ riskanovia30@gmail.com,putriyuliamz@gmail.com
}

\begin{abstract}
Abstrak
Penelitian ini bertujuan untuk mengetahui apakah terdapat hubungan antara adversity quotientterhadap prestasi akademik mahasiswa Program Studi Pendidikan Matematika di Universitas Riau Kepulauan Batam.Jenis penelitian ini yaitu penelitian korelasional dengan populasi adalah keseluruhan mahasiswa Program Studi Pendidikan Matematika.Dalam penelitian ini sampel yang digunakan adalah mahasiswa aktif angkatan 2015, 2014, dan 2013 sebanyak 124 mahasiswa.teknik pengambilan sampel yaitu menggunakan purposive sampling. Instrumen yang digunakan berupa angket adversity quotient yang telah diuji validitas dan reliabilitasnya.Teknik analisa yang digunakan dalam penelitian ini untuk menguji hipotesisnya dengan menggunakan rumus korelasi parsial yang dilakukan dengan bantuan software SPSS versi 20.Hasil penelitian ini menunjukkan bahwa terdapat hubungan yang positif dan signifikan antara adversity quotientterhadap prestasi akademik mahasiswa Program Studi Pendidikan Matematika di Universitas Riau Kepulauan Batam. Dengan besar korelasi $r=0,384$, arah hubungan positif karena nilai $r$ positif dan besarnya sumbangan yang diberikan oleh adversity quotient terhadap prestasi akademik mahasiswa sebesar $14,75 \%$. Selanjutnya, nilai signifikansi $0,00<0,05$. Artinya adalah semakin tinggi adversity quotient mahasiswa maka akan semakin tinggi pula prestasi akademik mahasiswa tersebut dan begitu juga sebaliknya.
\end{abstract}

Kata Kunci: adversity quotient, prestasi akademik, mahasiswa.

\begin{abstract}
The aims of this research to determine correlation between adversity quotient and students' academic achievement of Mathematics Education Studies at the Riau Kepulauan University. This research used correlational research type. The selection of research subject used purposive sampling with total of the subject was 124 students. The instrument of this research was valid and reliable questionnaires. This research was analyzed by using correlational analysis with SPSS programme. From the result of the research, it was found that positif and signifikan correlation between adversity quotient and students' academic achievement of Mathematics Education Studies at the Riau Kepulauan University. With correlation coefficient $r=0,384$ while determinant coefficient was showed by $r$ square $=0,1475$ which means that $14,75 \%$ given by adversity quotient on students achievements. Furthermore, the significance value is $0.00<0.05$. This means that the higher the adversity quotient the student will be the higher the student's academic achievement and vice versa.
\end{abstract}

Keywords: adversity quotient, academic achievement, students 


\section{PENDAHULUAN}

Dalam berbagai tahap kehidupan setiap individu menghadapi berbagai kesulitan, tantangan, kerugian dan berbagai masalah lainnya.Namun, masing-masing individu memiliki kemampuan untuk mengatasi kesulitan tersebut.Stoltz (2000) mendefinisikan Adversity Quotient $(A Q)$ sebagai kemampuan seseorang dalam mengamati kesulitan dan mengolah kesulitan tersebut dengan kecerdasan yang dimiliki sehingga menjadi sebuah tantangan untuk menyelesaikannya.Terutama dalam pencapaian sebuah tujuan, cita-cita, harapan dan yang paling penting adalah kepuasan pribadi dari hasil kerja atau aktivitas itu sendiri.Selain itu, menurut Phoolka \& Kaur (2012) $A Q$ adalah prediktor keberhasilan seseorang yang menghadapi kesulitan, bagaimana dia berprilaku dalam situasi sulit, bagaimana dia mengendalikan situasi, serta apakah dia bisa menemukan asal usul permasalahan dan optimis bahwa kesulitan yang dialaminya akan berakhir. $A Q$ juga merupakan bentuk respons seseorang terhadap berbagai macam masalah atau bagaimana mereka bereaksi terhadap dunia disekitar mereka (Stoltz \& Weihenmayer dalam Cornista \& Macasaet, 2013)

Pribadi dengan $A Q$ tinggi akan mampu mencari jalan keluar atau solusi dari masalahnya dengan berupaya memecahkan sumber masalahnya langsung, bukan dengan berkeluh-kesah dan bergantung pada orang lain. Pribadi dengan $A Q$ tinggi akan tangguh berjuang menghadapi kesulitan dan menaklukkannya. Pentingnya $A Q$ dalam pembelajaran dikemukakan oleh Leman (2007:125) yang menyatakan bahwa kemampuan memecahkan masalah, daya tahan menghadapi masalah, dan keberanian mengambil resiko merupakan salah satu faktor yang mempengaruhi kesuksesan.Semakin tinggi tingkat $A Q$ semakin besar kemungkinan seseorang untuk bersikap optmis, dan inovatif dalam memecahkan masalah.Sebaliknya, semakin rendah tingkat $A Q$ semakin besar kemungkinan seseorang untuk menyerah, menghindari tantangan dan mengalami depresi.IQ sebagai kecerdasan seseorang dalam menghadapi kesulitan membantu mahasiswa meningkatkan potensi diri dan menjalani kehidupan yang lebih baik.

Mahasiswa pada umumnya berada pada masa dewasa awal, yaitu usia sekitar 18-22 tahun yang mana memiliki salah satu ciri khas sebagai usia banyak masalah (Rita, 2008) Kadison \& DiGeronimo (2005) mengungkapkan masalah-masalah yang kerap dialami mahasiswa di antaranya yaitu perbedaan latar belakang, perbedaan budaya, status ekonomi, gaya hidup dengan teman yang berada di lingkungan kampus, serta motivasi rendah karena program studi yang tidak sesuai dengan yang diinginkan, dan masalah ekonomi yang membuat mahasiswa perlu bekerja untuk memenuhi kebutuhannya. Mayoritas mahasiswa UNRIKA adalah pekerja di perusahaan sehingga jadwal kuliah terbagi dua yaitu, kelas pagi dari jam 09.00-15.30 WIB dan kelas malam dari jam 17.0022.00 WIB. Mereka mengikuti perkuliahan setelah pulang bekerja.Beberapa masalah yang sering 
dikeluhkan oleh mahasiswa diantaranya adalah aktivitas mereka yang sangat padat bekerja dan kuliah membuat mereka tertekan apalagi dengan banyaknya tugas yang diberikan oleh dosen.Selain itu, mahasiswa merasa kesulitan dalam memahami materi yang diajarkan dan juga permasalahan ekonomi.Masalah-masalah tersebut dapat berimbas pada prestasi akademik mahasiswa.

Bagi seorang mahasiswa, khususnya mahasiswa program studi pendidikan matematika yang sedang belajar tidak menutup kemungkinan akan banyak sekali hambatan dalam proses perkuliahan yang berlangsung. Terlebih lagi dalam pembelajaran matematika.Obyek matematika yang abstrak dapat menyebabkan mahasiswa kesulitan mempelajarinya, kesulitan tersebut tidak hanya terjadi pada saat mahasiswa berusaha memahami, menemukan jawaban dari masalah matematika, tetapi dapat pula terjadi saat mahasiswa harus berinteraksi di dalam kelompoknya, dan saat berkomunikasi mempertahankan pendapatnya.Disinilah potensi $A Q$ sangat dibutuhkan dalam belajar matematika, karena belajar pada dasarnya adalah mengatasi kesulitan.

Peneliti terdahulu menguraikan bahwa prestasi akademik ditentukan oleh Intellegence Quotient (IQ) dan Emotional Quotient (EQ).tetapi, penelitian terbaru ini menunjukkan bahwa $A Q$ merupakan indeks yang lebih baik dalam mencapai kesuksesan selain IQ dan EQ (Siphai, 2015). Prestasi akademik dapat dianggap sebagai penguasaan mata kuliah tertentu yang telah ditentukan oleh fakultas, jurusan atau program studi. Ahmadi (2008: 130) menyatakan bahwa prestasi akademik adalah "hasil interaksi antara beberapa faktor yang mempengaruhinya baik dari dalam diri (faktor internal) maupun dari luar diri (faktor eksternal) individu dalam belajar".Selanjutnya Winkel (dalam Udiyono, 2011) menyatakan bahwa prestasi adalah bukti keberhasilan usaha yang telah dicapai.Hasil penelitian Huijuan (2009) menunjukkan bahwa ada hubungan yang signifikan antara AQ dengan performa akademik mahasiswa.

\section{METODOLOGY}

Jenis penelitian yang digunakan dalam penelitian ini adalah penelitian korelasional. Siregar (2013: 70) menyatakan bahwa penelitian korelasi atau korelasional bertujuan untuk mengetahui hubungan dan tingkat hubungan antara dua variabel atau lebih tanpa ada upaya untuk mempengaruhi variabel tersebut sehingga tidak terdapat manipulasi variabel.

Penelitian ini dilakukan di Universitas Riau Kepulauan khususnya di Program Studi Pendidikan Matematika selama 6 bulan dari bulan April sampai September 2017. Adapun populasi dalam penelitian ini yaitu mahasiswa Program Studi Pendidikan Matematika, sedangkan sampel penelitian adalah mahasiswa aktif angkatan 2015, 2014, dan 2013 yang terdiri 
dari 124 orang. Teknik pengambilan sampel yaitu purposive sampling. Variabel dalam penelitian ini terdiri dari variabel bebas dan variabel terikat. Variabel bebas yaitu AQmahasiswa, sedangkan variabel terikat yaitu prestasi akademik mahasiswa. Instrumen untuk mengumpulkan data pada penelitian ini disusun dalam bentuk angket/kuisioner AQ. Angket AQ terdiri dari pernyataan positif dan negatif, dengan indikator AQ yang digunakan yaitu, (1) kendali diri, (2) asal-usul dan pengakuan diri, (3) jangkauan, dan (4) daya tahan.Sedangkan prestasi akademik diambil dari IPK mahasiswa yang diperoleh dari BAAK FKIP UNRIKA.

Teknik analisis instrumen meliputi uji validitas dan reliabilitas. Uji validitas yang dilakukan meliputi uji validitas isi dan konstruk. Validitas isi dalam penelitian ini dilakukan dengan meminta pertimbangan ahli (judgment) yang berkompeten dengan bidang yang diteliti, dalam hal ini yang bertindak sebagai ahli adalah dengan Dosen Bimbingan Konseling dengan konsentrasi Psikologi. Setelah validasi ahli dilaksanakan, hasil validasi tersebut dijadikan dasar untuk merevisi instrumen tes. Selanjutnya dilakukan ujicoba instrumen pada mahasiswa Program Studi Pendidikan Matematika angkatan 2016 yang terdiri dari satu kelas dengan jumlah 35 orang mahasiswa. Setelah ujicoba dilanjutkan dengan pengujian validitas konstruk menggunakan rumus Product Moment dengan bantuan software SPSS versi 20.

Berdasarkan perhitungan uji validitas pertamauntuk angket $A Q$ dengan menggunakan bantuan software SPSS versi 20, yang terdiri dari 50 item pernyataan diperoleh 29 item pernyataan yang tidak valid, sedangkan terdapat 21 item yang valid. Selanjutnya, pernyataan yang valid, diuji validitas yang kedua untuk melihat apakah masih ada pernyataan yang tidak valid.Berdasarkan perhitungan uji validitas kedua yang dilakukan pengujian dengan menggunakan rumus dan ketentuan yang sama seperti pengujian validitas pertama, maka didapat hasil semua butir pernyataan dinyatakan valid.Sehingga pernyataan $A Q$ yang valid dilanjutkan dengan uji reliabilitas.

Uji reliabilitas instrumen dalam penelitian ini menggunakan rumus Alpha Cronbach.Siregar (2013: 90) menyatakan bahwa kriteria suatu instrument dikatakan reliable apabila reliabilitas $\left(r_{11}\right)>0$ 0.6.Perhitungan reliabilitas dibantu dengan menggunakan software SPSS versi 20. Adapun hasil perhitungannya diperoleh $r_{11}=0,834$ yang artinya $r_{11}>0.6$, sehingga dapat disimpulkan bahwa angket AQ reliabel dan dapat digunakan untuk pengambilan data penelitian.

Selanjutnya analisis data yang digunakan untuk menjawab hipotesis penelitian adalah uji korelasional parsial, dengan uji prasyarat yaitu uji normalitas.Pengujian normalitas dalam penelitian ini menggunakan uji Kolmogorov Smirnov dengan bantuan SPSS 20 untuk melihat apakah data berdistribusi normal atau tidak. Kriterianya yaitu jika probabilitas (sig.) $\geq 0,05$ maka 
data berdistribusi normal dan sebaliknya. Uji korelasi yang digunakan yaitu uji korelasi Product Moment dengan bantuan SPSS versi 20 dengan kriteria pengujiannya jika nilai $\leq 0,05$ maka terdapat hubungan yang signifikan antara kedua variable dan sebaliknya.Kemudian dilanjutkan dengan mencari Koefisien Determinasi (KD) yaitu untuk melihat seberapa besar sumbangan yang diberikan oleh variable bebas terhadap variable terikat.

\section{PEMBAHASAN}

Data yang diperoleh dari hasil penelitian ini didapatkan melalui angket AQ yang terdiri dari 21 pernyataan yang disebarkan kepada 124 orang mahasiswa prodi pendidikan matematika dan juga IPK mahasiswa yang diperoleh dari BAAK FKIP UNRIKA.Adapun deskripsi data AQ dan prestasi akademik mahasiswa dapat dilihat pada tabel berikut.

Tabel 1. Deskripsi data AQ dan Prestasi Akademik Mahasiswa

\begin{tabular}{ccc}
\hline Deskripsi & $\begin{array}{c}\text { Adversity Quotient } \\
(\mathrm{AQ})\end{array}$ & $\begin{array}{c}\text { Prestasi Akademik } \\
\text { Mahasiswa }\end{array}$ \\
\hline$N$ & 7993 & 400,11 \\
\hline Mean & 64,5 & 3,23 \\
\hline Std.Deviation & 6,56 & 0,44 \\
\hline Minimum & 50 & 1,27 \\
\hline Maximum & 78 & 3,93 \\
\hline Min ideal & 0 & 0 \\
\hline Maxideal & 84 & 4,00
\end{tabular}

Berdasarkan tabel di atas, terlihat bahwa rata-rata AQ mahasiswa yaitu 64,5 dan prestasi akademik mahasisa 3,23. Selanjutnya dari data yang diperoleh dilakukan uji normalitas dengan hasil sebagai berikut:

Tabel 2. Uji Normalitas Data

\begin{tabular}{cccc}
\hline & \multicolumn{3}{c}{ Kolmogorov-Smirnov } \\
\cline { 2 - 4 } & Statistic & $d f$ & Sig. \\
\hline AQ & 0,068 & 124 & 0,200 \\
\hline Prestasi Akademik & 0,055 & 124 & 0,200 \\
\hline
\end{tabular}

Data dikatakan normal jika probabilitas (sig.) $\geq 0,05$, berdasarkan data di atas diperoleh nilai sig. dari AQ dan prestasi akademik 0,200 yang artinya lebih besar dari 0,05, sehingga dapat disimpulkan bahwa kedua data berdistribusi normal.

Selanjutnya dilakukan uji hipotesis penelitian dengan menggunakan korelasi product moment dengan hasil sebagai berikut. 
Tabel 3. Hasil Uji Analisis Data

\begin{tabular}{|c|c|c|c|}
\hline \multicolumn{4}{|c|}{ Correlations } \\
\hline & & $\mathrm{AQ}$ & Prestasi \\
\hline \multirow[t]{3}{*}{$\mathrm{AQ}$} & Pearson Correlation & 1 & $.384^{* * *}$ \\
\hline & Sig. (2-tailed) & & .000 \\
\hline & $\mathrm{N}$ & 124 & 124 \\
\hline \multirow[t]{3}{*}{ Prestasi } & Pearson Correlation & $.384^{* *}$ & 1 \\
\hline & Sig. (2-tailed) & .000 & \\
\hline & $\mathrm{N}$ & 124 & 124 \\
\hline
\end{tabular}

Berdasarkan tabel di atas, diperoleh nilai $r=0,384$ yang artinya hubungan tersebut bernilai positif antara AQ dengan prestasi akademik mahasiswa. Selanjutnya, diperoleh nilai sig. $=0,000<0,05$, sehingga dapat disimpulkan bahwa terdapat hubungan yang positif signifikan. Hal ini sejalan dengan hasil penelitian Nurhayati (2015) bahwa $A Q$ berpengaruh secara signifikan terhadap prestasi belajar matematika, selanjutnya penelitian Huijuan (2009) menunjukkan bahwa ada hubungan yang signifikan antara AQ dengan performa akademik mahasiswa.

Besarnya sumbangan yang diperikan oleh AQ terhadap prestasi akademik mahasiswa yaitu.

$$
\begin{aligned}
& K D=r^{2} \times 100 \% \\
& K D=0,384^{2} \times 100 \% \\
& K D=14,75 \%
\end{aligned}
$$

Sehingga dapat ditarik kesimpulan bahwa besarnya sumbangan AQ terhadap prestasi akademik yaitu $14,75 \%$, sedangkan $85,25 \%$ lainnya dipengaruhi oleh faktor lain yang tidak diteliti dalam penelitian ini.

Terdapat hubungan positif dan signifikan antara adversity quotientdengan Prestasi Akademik mahasiswa artinya semakin tinggi adversity quotient mahasiswa tersebut maka semakin tinggi juga prestasi akademiknya, hal ini juga berlaku sebaliknya. Hubungan yang positif tersebut dapat disebabkan oleh beberapa hal, diantaranya mahasiswa yang memiliki adversity quotientmaka mahasiswa itu akan memiliki kemampuan dalam mengamati kesulitan dan mengolah kesulitan yang dihadapi tersebut dengan kecerdasan yang dimiliki sehingga menjadi sebuah tantangan untuk menyelesaikan permasalahannya. 
Mahasiswa yang memiliki adversity quotientyang tinggi mampumerupakan orang yang memilih untuk terus bertahan untuk berjuang menghadapi berbagai macam hal diantaranya kesulitan mempelajari matematika, kesulitan memahami pelajaran, menemukan jawaban dari masalah matematika, dan juga kesulitan mahasiswa dalam berinteraksi di dalam kelompoknya, serta saat berkomunikasi mempertahankan pendapatnya. Kemampuan untuk tetap berjuang menghadapi berbagai macam permasalah tersebut terlihat dari kemampuan mahasiswa untuk mengontrol diri, menempatkan perasaan dirinya dengan berani menanggung akibat dari situasi yang ada, sehingga menciptakan pembelajaran dalam melakukan perbaikan atas masalah yang terjadi.

Selain itu mahasiswa yang memiliki adversity quotientyang tinggi terlihat juga dari kemampuan untuk menjangkau dan membatasi masalah agar tidak menjangkau bidang-bidang yang lain serta kemampuan dalam mempersepsi kesulitan, dan kekuatan dalam menghadapi kesulitan tersebut dengan menciptakan ide dalam pengatasan masalah sehingga ketegaran hati dan keberanian dalam penyeleasaian masalah dapat terwujud.

Sedangkan mahasiswa yang kurang memiliki adversity quotientterlihat dari orang rendahnya kemampuan untuk terus bertahan untuk menghadapi berbagai macam permasalahan ini terlihat dari sifat mudah putus asa, kurang kontrol diri, tidak adanya kemauan untuk berusaha menyelesaikan permasalahan yang dihadapi Hal ini sejalan dengan pendapat Stoltz (2000) yang menyatakan bahwa siswa yang memiliki adversity quotient tinggi akan merasa tertantang untuk menyelesaikan masalah yang diajukan, dan menyelesaikan masalah tersebut dengan gigih, ulet, dan keyakinan bahwa segala hal bisa terlaksana.

\section{KESIMPULAN DAN SARAN}

\section{Kesimpulan}

Berdasarkan analisis data dan pembahasan di atas dapat disimpulkan bahwa terdapat hubungan yang positif dan signifikan antara adversity quotient dan prestasi akademik mahasiswa, dengan besar sumbangan yang diberikan oleh adversity quotient yaitu sebesar $14,75 \%$.

\section{Saran}

Peneliti selanjutnya diharapkan dapat meneliti lebih lanjut tentang tingkatan adversity quotient, faktor-faktor yang mempengaruhi adversity quotient sehingga lebih memperkaya ilmu pengetahuan melalui hasil penelitian.Selain itu, diharapkan adanya kegiatan sosialisasi tentang pentingnyaadversity quotient di Universtas Riau Kepulauan, sehingga mahasiswa menjadi 
terdorong untuk berjuang menghadapi kesulitan yang dialami selama menjalani perkuliahan.

\section{REFERENSI}

Ahmadi, A. 2008. Psikologi Belajar. Jakarta: PT. Rineka Cipta.

Cornista, Guillian AL \& Macasaet, Charmaine JA. (2013). Adversity Quotient ® and Achievement Motivation of Selected Third Year and Fourth Year Psychology Students of De La Salle Lipa A.Y. 2012- 2013. Thesis. The Faculty of the Collegeof Education, Art, and Sciences- De La Sale Lipa.

Huijuan, Zhou. 2009. The Adversity Quotient and Academic Performance Among College Students at St. Joseph's College Quezon City. Thesis. The Department of Arts and Sciences St. Joseph's College, Quezon City.

Kadison, Richard M.D \& DiGeronimo, Theresa F. 2005. College of the Overwhelmed The Campus Mental Health Crisis and What to Do About It. Journal of College Student Development. Vol. 46(5): 556-558.

Leman. 2007. The Best of Chinese Life Philosophies. Jakarta: Gramedia Pustaka Utama.

Nurhayati \& Noram F. 2015. Pengaruh Adversity Quotient (AQ) dan Motivasi Berprestasi terhadap Prestasi Belajar Matematika.Jurnal Formatif. Volume 3(1): 72-77.

Rita Eka Izzaty. 2008. Perkembangan Peserta Didik. Yogyakarta: UNY Press.

Shipai, Sunan. 2015. Influences of moral, emotional and adversity quotient on good citizenship of Rajabhat University's Students in the Northeast of Thailand. AcademicJournals. Vo. 10(17):2413-2421.

Siregar, Sofyan. 2013. Metode Penelitian Kuantitatif Dilengkapi dengan Perbandingan Perhitungan Manual Spss. Jakarta: Kencana.

Stoltz, P. G. 2000. Adversity Quotient, Mengubah Hambatan Menjadi Peluang. Jakarta: Terjemahan, PT Gramedia Widiasarana Indonesia.

Udiyono. 2011. Pengaruh motivasi orang tua, kondisi lingkungan dan disiplin belajar terhadap prestasi akademik mahasiswa pendidikan matematika Universitas Widya Dharma Klaten semester gasal Tahun Akademik 2010/2011. Magistra No. 75 Th. XXIII Maret 2011. ISSN 0215-9511. http://journal.unwidha.ac.id/index.php/magistra/article/viewFile/80/41diakses 10 Maret 2016 